\title{
Problem Based Instruction sebagai alternatif Model Pembelajaran Fisika di SMA
}

\author{
Prayekti \\ FKIP-Universitas Terbuka, email: prayekti@mail.ut.ac.id
}

\begin{abstract}
Abstrak: Penelitian ini dilakukan untuk membuktikan model Problem Based Instructional (PBI) dapat meningkatkan hasil belajar, aktivitas dan respon siswa dalam pembelajaran. Model diterapkan pada 2 kelas XI paralel SMA Swasta di Jakarta Selatan. kelas XI IPA1 dan kelas XI IPA2 Siswa kelas XI IPA1 diberikan treatment dengan menerapkan model pembelajaran PBI sedangkan untuk kelas XI IPA2 dilakukan pembelajaran klasikal seperti biasa. Hasil penerapan model pembelajaran PBI treatment pertama diperoleh hasil Kelas XI IPA1 nilai rata-rata terendah untuk pretes 3,25 sedangkan nilai ratarata tertinggi 6,75. Sementara itu untuk kelas XI IPA2 nilai rata-rata terendah 3,25 dan tertinggi 6,25. Postes untuk kelas pertama nilai rata-rata terendah 6,45 dan tertinggi 8,75 , sedangkan postes untuk kelas XI IPA2 nilai rata-rata terendah 6,75 dan nilai tertinggi sebesar 9,00. Pada treatment kedua kelas XI IPA1, nilai rata-rata siswa terendah 5,00 dan nilai rata-rata tertinggi 7,35, sedangkan kelas XI IPA2 nilai rata-rata terendah 6,45 dan tertinggi 8,5 . Pada treatment ketiga hasil pretes diperoleh nilai ratarata siswa kelas XI IPA1 terendah 3,25 dan tertinggi 4,25. Nilai rata-rata postes terendah yang diperoleh siswa 1 adalah 7,25 dan tertinggi 9,75. Untuk kelas XI IPA22 nilai rata-rata siswa pada pretes terendah 3,00 dan tertinggi 4,5 sedangkan nilai postes rata-rata terendah 7,00 dan tertinggi 9,00. Pada akhirnya, guru dapat merancang model pembelajaran PBI dengan baik dan dapat memotivasi siswa terlibat aktif pada kegiatan pemecahan masalah, mendefinisikan dan mengorganisasikan tugas belajar serta menentukan langkah-langkah memecahkan masalah.
\end{abstract}

Kata kunci: problem based instruction, kerja kelompok,dan lembar kerja siswa

\begin{abstract}
This research was conducted to prove the PBI model can improve learning outcomes, activities and responses of students in learning. The model is applied to two classes XI of High school in South Jakarta. The first is class-XI of IPA1 and the other is class-XI of IPA2. IPA1 given treatment by applying PBI learning model, while for class-XI IPA2 performed as conventional classical learning. After the application of learning models obtained PBI's first treatment of Class-XI of IPA1 average value for the lowest pretes is 3.25 while the average value is the highest 6.75. Meanwhile, for class-XI of IPA2, value of the lowest average is 3.25 and the highest is 6.25 . Posttes for first-class average score is 6.45 and the lowest the highest is 8.75 , whereas for class XI posttes value IPA2 lowest average is 6.75 and the highest value of 9.00. In the second treatment available, IPA1 class-XI, the average value of the lowest student score is 5.00 and the highest average is 7.35, while for class-XI IPA2 average value is 6.45 the lowest and the highest is 8.5. In the third treatment results obtained pretes average grade XI of IPA1 lowest and the highest 3.25 for 4.25 . and the average value posttes students obtained the lowest IPA1 is 7.25 and the highest 9.75. For class-XI IPA2 average score of students in the lowest pretes is 3.00 and the highest is 4.5. While the value posttes lowest average is 7.00 and the highest is 9.00. At first teachers were not used but the implementation of the third treatment teachers have mastered the learning model PBI well. Teachers have been able to design a model of the PBI with a good learning, teachers have been able to motivate students actively involved in problem-solving activities, define and organize learning tasks and determine the steps to solve the problem. Teachers motivate students to do reflection, and have been able to evaluate the process of investigations conducted so that students can understand their weaknesses and shortcomings of the reflection done.
\end{abstract}

Keywords: Problem Based Instruction, working groups, Student Worksheet 


\section{Pendahuluan}

Hasil belajar siswa pada mata pelajaran fisika masih belum sesuai harapan. Rendahnya hasil belajar siswa ini tidak terlepas dari proses pembelajaran yang dilaksanakan oleh guru di kelas. Guru adalah orang yang memegang peranan penting dalam pembentukan sumber daya manusia yang berkualitas. Dalam pembelajaran fisika guru dapat menerapkan berbagai macam strategi pembelajaran dan berbagai variasi metode, namun hasil belajar siswa belumlah optimal. Hasil observasi awal menunjukkan bahwa strategi dan metode pembelajaran yang diterapkan guru kurang memperhatikan proses pembentukan pengetahuan sehingga pembelajaran kurang bermakna bagi siswa. Selain itu, interaksi dan komunikasi antara guru dan siswa maupun antar siswa kurang berjalan dengan baik. Salah satu upaya untuk mengatasi permasalahan tersebut, model pembelajaran Problem Based Instructional (PBI) menjadi alternatif model pembelajaran yang dapat diterapkan guru dalam pembelajaran fisika di kelas yang dapat meningkatkan hasil belajar, aktivitas dan respon siswa dalam pembelajaran.

Dalam menjelaskan konsep-konsep fisika guru masih menerapkan metode ceramah dan pemberian tugas saja. Siswa tidak pernah diperkenalkan dengan kerja di laboratorium atau praktikum fisika. Siswa tidak dilatih untuk membuktikan suatu teori atau konsep fisika, demikian juga siswa tidak pernah mengalami kerja ilmiah seperti para ahli fisika melakukannya untuk menemukan teori ataupun membuktikan kebenaran suatu teori. Pembelajaran masih didominasi oleh kegiatan guru saja, siswa bersikap pasif, hanya diam saja mendengarkan penjelasan guru.

Teori belajar yang paling mendasari model pembelajaran PBI adalah teori belajar penemuan (discovery learning) merupakan teori belajar penemuan sesuai dengan pembentukan pengetahuan secara aktif oleh manusia, dan dengan sendirinya memberikan hasil yang paling baik. Berusaha sendiri untuk mencari pemecahan masalah serta pengetahuan yang menyertainya sehingga menghasilkan pengetahuan yang benarbenar bermakna. Persepsi seseorang tentang suatu peristiwa merupakan suatu proses konstruktif. Jadi seseorang tidak dianggap sebagai organisme yang pasif tetapi seseorang yang memilih informasi secara aktif. Pengetahuan yang diperoleh melalui belajar penemuan memiliki beberapa kebaikan yaitu pengetahuan yang diperoleh lebih bertahan lama, memiliki efek transfer yang lebih baik, meningkatkan penalaran siswa dan kemampuan berpikir bebas.

Model pembelajaran PBI diharapkan dapat menjadi model alternatif yang digunakan guru dalam mengajar fisika di kelas. Pada pelaksanaannya, siswa diminta membentuk dalam kelompok-kelompok kecil dan diberi tugas untuk membahas topik fisika dan melakukan kerja kelompok untuk melaksanakan percobaan. Dalam pengaturan kelompok belajar diupayakan semua siswa dapat terlibat aktif pada kegiatan penyelesaian masalah sehingga dapat mencapai hasil yang optimal. Dengan demikian keterbatasan model pembelajaran PBI dapat diatasi.

Penelitian ini dimaksudkan untuk mengembangkan model PBI guna meningkatkan hasil belajar siswa dalam pelajaran fisika. Dalam penelitian ini pengembangan perangkat pembelajaran dimulai pada tahap pengembangan sampai dengan tahap uji coba. Apabila memungkinkan perangkat yang digunakan dapat disebarkan ke sekolah-sekolah yang lain artinya perangkat tersebut digunakan pada sekolah uji coba.

Berdasarkan latar belakang yang telah diuraikan sebelumnya, maka yang menjadi perumusan masalah adalah dengan mengembangkan model pembelajaran PBI diharapkan pembelajaran fisika menjadi efektif dan dapat meningkatkan hasil belajar siswa. Adapun tujuan penelitian adalah sebagai berikut. 1) Merancang model pembelajaran Problem Based Instruction; 2) Mengembangkan model pembelajaran PBI untuk mata pelajaran Fisika; 3) menerapkan model pembelajaran Problem Based Instruction untuk mata pelajaran fisika di kelas XI. Penerapan model pembelajaran Problem Based Instruction dalam pelajaran fisika sebagai masukan yang berharga bagi guru fisika dan sebagai model alternatif dalam mengajarkan fisika di SMA serta memberi pengalaman baru bagi guru maupun siswa. 


\section{Kajian Literatur}

Guru sebagai agen pembelajaran haruslah memiliki berbagai kompetensi. Komptensi merupakan kebulatan penguasaan pengetahuan, keterampilan, dan sikap yang ditampilkan melalui unjuk kerja. Kepmendiknas No. 045/U/2002 Pasal 1 menyebutkan kompetensi sebagai seperangkat tindakan cerdas dan penuh tanggung jawab yang dimiliki seseorang sebagai syarat untuk dianggap mampu oleh masyarakat dalam melaksanakan tugas-tugas sesuai dengan pekerjaan tertentu. Kompetensi guru dapat dimaknai sebagai kebulatan pengetahuan, keterampilan dan sikap yang terwujud tindakan cerdas dan penuh tanggung jawab dalam melaksanakan tugas sebagai agen pembelajaran. Undang-undang Guru dan Dosen tercakup pada undang-undang No 14 tahun 2005 menyatakan kompetensi guru meliputi kompetensi kepribadian, pedagogik, profesional dan sosial. Dari keempat kompetensi di atas, kompetensi pedagogik merupakan kajian dalam penelitian ini. Kompetensi pedagogik meliputi pemahaman terhadap siswa, perencanaan dan pelaksanaan pembelajaran, evaluasi hasil belajar, dan pengembangan peserta didik untuk mengaktualisasikan berbagai potensi yang dimilikinya. Secara rinci setiap subkompetensi dapat dijabarkan menjadi indikator esensial sebagai berikut: 1) Subkompetensi memahami peserta didik secara mendalam memiliki indikator essensial: memahami peserta didik dengan memanfaatkan prinsip-prinsip kepribadian dan mengidentifikasi bekal ajar awal peserta didik; 2. Merancang pembelajaran, termasuk memahami landasan pendidikan untuk kepentingan pembelajaran. Subkompetensi ini memiliki indikator esensial: memahami landasan kependidikan; menerapkan teori belajar dan pembelajaran; menentukan strategi pembelajaran berdasarkan ka-rakteristik peserta didik, kompetensi yang ingin dicapai, materi ajar dan menyusun rancangan pembelajaran berdasarkan stretegi yang dipilih; 3 . Subkompetensi melaksanakan pembelajaran memiliki indikator esensial: menata latar (setting) pembelajaran; dan melaksanakan pembelajaran yang kondusif; 4. Subkompetensi merancang dan melaksanakan evaluasi pembelajaran memiliki indikator esensial: merancang dan melaksanakan evaluasi (assessment) proses dan hasil belajar secara berkesinambungan dengan berbagai metod; menganalisis hasil evaluasi proses dan hasil belajar untuk menentukan tingkat ketuntasan belajar (mastery learning); dan memanfaatkan hasil penilaian pembelajaran untuk perbaikan kualitas program pembelajaran secara umum; 5) Subkompetensi mengembangkan peserta didik untuk mengaktualisasikan berbagai potensinya, memiliki indikator esensial : memfasiltasi peserta didik untuk pengembangan berbagai potensi akademik ; dan memfasilitasi peserta didik untuk mengembangkan berbagai potensi nonakademik/

\section{Problem Based Instruction (PBI)}

Merujuk kepada penelitian yang dilakukan oleh Nurhayati dalam skripsi online Pengembangan model pembelajaran Problem Based Instruction merupakan proses memperluas, memvariasikan atau memperbaiki sesuatu yang sudah ada. Salah satu ciri khusus model pembelajaran yang tidak dimiliki oleh strategi atau prosedur tertentu yaitu tingkah laku mengajar (sintaks) yang menggambarkan pola kegiatan guru dan siswa dalam berinteraksi sehingga tujuan pembelajaran dapat tercapai. Pengembangan model merupakan suatu usaha yang sistematis untuk menganalisis masalah, mengidentifikasi, memilih, merancang, dan menilai pemecahannya. Selanjutnya, pengembangan model pembelajaran mempunyai tiga prinsip dasar yang berfokus pada siswa, menggunakan pendekatan sistem dan pemanfaatan sumber belajar secara maksimal supaya tercipta proses pembelajaran yang efektif dan efisien.

Model pembelajaran yang dikembangkan pada penelitian adalah model Problem Based Instruction (PBI). PBI memiliki ciri yang berbeda dengan model pembelajaran langsung, pada pembelajaran langsung guru mendemonstrasikan dan menginformasikan secara detail langkahlangkah yang harus dikerjakan. Tetapi pada model pembelajaran berbasis masalah diawali dengan menyajikan masalah kepada siswa. Masalah ini harus otentik atau nyata dalam kehidupan seharihari berupa fakta-fakta atau fenomena yang sering dijumpai siswa. Model pembelajaran berbasis masalah ini disajikan dalam bentuk 
penyelidikan dan inkuiri sehingga dapat memberikan kemudahan bagi siswa untuk memperoleh konsep-konsep.

Peran guru dalam PBI salah satunya adalah mengajukan masalah dan memfasilitasi penyelidikan serta melakukan dialog dengan siswa, sampai masalah tersebut terpecahkan. Masalah yang diajukan guru diperoleh dari situasi kehidupan nyata dan memerlukan berpikir tingkat tinggi dan untuk mengundang berbagai pemecahan masalah. Adapun ciri-ciri utama PBI meliputi suatu pengajuan pertanyaan atau masalah, melakukan penyelidikan autentik dan kerjasama antar siswa. PBI didasarkan pada teori belajar psikologi kognitif dan pendekatan konstruktivis mengenai belajar dan sangat efektif untuk mengajarkan proses-proses berfikir tingkat tinggi. Diharapkan dengan PBI ini siswa dapat memproses informasi yang baru diperolehnya menjadi bermakna (Janulis P. Purba: 2003).

Pada awal perkembangannya, PBI lebih dikenal dengan istilah Problem Based Instructional (PBI). PBI merupakan suatu pendekatan pembelajaran yang menghadapkansiswa pada masalah dunia nyata untuk belajar. $P B I$ pertama kali dikembangkan oleh Barbara J Dutch pada pendidikan kedokteran awal tahun 1970 an dan dikemukakan bahwa In problem-based learning $(P B I)$, student are presented with an interesting, relevant problem "up front", so that they can experience for themselves the process of doing science.

Dua hal yang harus dijadikan pedoman dalam menyajikan permasalahan yaitu pertama bahwa permasalahan harus sesuai dengan konsep dan prinsip yang akan dipelajari dan kedua bahwa permasalahan yang disajikan harus real artinya sesuai dengan kehidupan sehari-hari siswa. Adapun fase-fase dalam penerapan model pembelajaran PBI menurut Survery dan Duffy (1995) adalah seperti Tabel 1.

Lingkungan belajar PBI dirancang sesuai dengan materi yang dibahas dan memberikan kesempatan untuk proses diskusi yang demokrasi sehingga siswa memiliki peranan yang aktif. Dalam pelaksanaan keseluruhan proses, guru membantu

Tabel 1. Fase-fase Penerapan Model Pembelajaran PBI

\begin{tabular}{|c|c|}
\hline FASE-FASE & TINGKAH LAKU GURU \\
\hline $\begin{array}{l}\text { 1. Orientasi siswa pada } \\
\text { masalah }\end{array}$ & $\begin{array}{l}\text { Menjelaskan tujuan pembelajaran; menjelaskan alat dan bahan yang } \\
\text { diperlukan; memotivasi siswa untuk terlibat pada kegiatan pemecahan } \\
\text { masalah }\end{array}$ \\
\hline $\begin{array}{l}\text { 2. Mengorganisasikan } \\
\text { siswa untuk belajar }\end{array}$ & $\begin{array}{l}\text { Membantu siswa mendefinisikan dan mengorganisasikan tugas belajar } \\
\text { yang berhubungan dengan masalah tersebut. }\end{array}$ \\
\hline $\begin{array}{l}\text { 3. Membimbing } \\
\text { penyelidikan individual } \\
\text { maupun kelompok }\end{array}$ & $\begin{array}{l}\text { Mendorong siswa untuk mengumpulkan informasi yang sesuai; Melak- } \\
\text { sanakan eksperimen untuk mendapatkan penjelasan dan pemecahan } \\
\text { masalah }\end{array}$ \\
\hline $\begin{array}{l}\text { 4. Mengembangkan dan } \\
\text { menyajikan hasil karya }\end{array}$ & $\begin{array}{l}\text { Membantu siswa dalam merencanakan dan menyiapkan karya yang } \\
\text { sesuai seperti laporan; Membantu siswa untuk berbagi tugas dengan } \\
\text { temannya }\end{array}$ \\
\hline $\begin{array}{l}\text { 5. Menganalisis dan } \\
\text { mengevaluasi proses } \\
\text { pemecahan masalah }\end{array}$ & $\begin{array}{l}\text { Membantu siswa untuk melakukan refleksi; Mengevaluasi terhadap } \\
\text { penyelidikan siswa dan proses yang siswa gunakan }\end{array}$ \\
\hline
\end{tabular}

sumber: Survery dan Duffy, 1995 
siswa untuk menjadi mandiri, otonom, percaya pada keterampilan intelektualnya, harus terlibat aktif dalam diskusi yang beorientasi inkuiri. Lingkungan belajar menekankan pada peranan sentral siswa bukan guru. PBI adalah metode yang menggunakan masalah sebagai langkah awal dalam mengumpulkan dan mengintegrasikan pengetahuan baru, sedangkan Menurut Suradijono (2004) PBI adalah metode yang menggunakan masalah sebagai langkah awal dalam mengumpulkan dan mengintegrasikan pengetahuan baru.

Menurut Boud \& Felleti (1991), dalam Saptono (2003) mengemukakan bahwa "Problem based learning is a way of constructing and teaching course using problem as a stimulus and focus on student activity"

\section{Fisika untuk Sekolah Menengah Atas (SMA)}

Fisika merupakan salah satu cabang IPA yang mendasari perkembangan teknologi maju dan konsep hidup harmonis dengan alam. Perkembangan pesat di bidang teknologi informasi dan komunikasi dewasa ini dipicu oleh temuan di bidang fisika material melalui penemuan piranti mikroelektronika yang mampu memuat banyak informasi dengan ukuran sangat kecil. Sebagai ilmu yang mempelajari fenomena alam, fisika juga memberikan pelajaran yang baik kepada manusia untuk hidup selaras berdasarkan hukum alam. Pengelolaan sumber daya alam dan lingkungan serta pengurangan dampak bencana alam tidak akan berjalan secara optimal tanpa pemahaman yang baik tentang fisika.

Pada tingkat SMA/MA, fisika dipandang penting untuk diajarkan sebagai mata pelajaran tersendiri dengan beberapa pertimbangan. Pertama, selain memberikan bekal ilmu kepada peserta didik, mata pelajaran Fisika dimaksudkan sebagai wahana untuk menumbuhkan kemampuan berpikir yang berguna untuk memecahkan masalah di dalam kehidupan seharihari. Kedua, mata pelajaran Fisika perlu diajarkan untuk tujuan yang lebih khusus yaitu membekali peserta didik pengetahuan, pemahaman dan sejumlah kemampuan yang dipersyaratkan untuk memasuki jenjang pendidikan yang lebih tinggi serta mengembangkan ilmu dan teknologi.
Pembelajaran Fisika dilaksanakan secara inkuiri ilmiah untuk menumbuhkan kemampuan berpikir, bekerja dan bersikap ilmiah serta berkomunikasi sebagai salah satu aspek penting kecakapan hidup

Mata pelajaran Fisika bertujuan agar peserta didik memiliki kemampuan sebagai berikut: 1) Membentuk sikap positif terhadap fisika dengan menyadari keteraturan dan keindahan alam serta mengagungkan kebesaran Tuhan Yang Maha Esa; 2) Memupuk sikap ilmiah yaitu jujur, obyektif, terbuka, ulet, kritis dan dapat bekerjasama dengan orang lain; 3) Mengembangkan pengalaman untuk dapat merumuskan masalah, mengajukan dan menguji hipotesis melalui percobaan, merancang dan merakit instrumen percobaan, mengumpulkan, mengolah, dan menafsirkan data, serta mengkomunikasikan hasil percobaan secara lisan dan tertulis; 4) Mengembangkan kemampuan bernalar dalam berpikir analisis induktif dan deduktif dengan menggunakan konsep dan prinsip fisika untuk menjelaskan berbagai peristiwa alam dan menyelesaian masalah baik secara kualitatif maupun kuantitatif; dan 5) Menguasai konsep dan prinsip fisika serta mempunyai keterampilan mengembangkan pengetahuan, dan sikap percaya diri sebagai bekal untuk melanjutkan pendidikan pada jenjang yang lebih tinggi serta mengembangkan ilmu pengetahuan dan teknologi.

Mata pelajaran Fisika di SMA/MA merupakan pengkhususan IPA di SMP/MTs yang menekankan pada fenomena alam dan pengukurannya dengan perluasan pada konsep abstrak yang meliputi aspek-aspek sebagai berikut: 1) Pengukuran berbagai besaran, karakteristik gerak, penerapan hukum Newton, alat-alat optik, kalor, konsep dasar listrik dinamis, dan konsep dasar gelombang elektromagnetik; 2) Gerak dengan analisis vektor, hukum Newton tentang gerak dan gravitasi, gerak getaran, energi, usaha, dan daya, impuls dan momentum, momentum sudut dan rotasi benda tegar, fluida, termodinamika; dan 3) Gejala gelombang, gelombang bunyi, gaya listrik, medan listrik, potensial dan energi potensial, medan magnet, gaya magnetik, induksi elektromagnetik dan arus bolak-balik, gelombang elektromagnetik, radiasi benda hitam, teori atom, relativitas, radioaktivitas. 


\section{Materi Gerak Parabola di Kelas XI IPA SMA}

Pada penelitian ini, kami mencoba pembelajaran berbasis masalah atau yang biasa disingkat PBI (Problem Based Instruction) pada topik gerak parabola. Materi kinematika adalah mengkaji gerak benda tanpa memperhitungkan gaya-gaya yang bekerja pada benda itu. Beberapa asumsi penyederhanaan yang digunakan dalam membahas gerak parabola dalam kajian ini adalah bahwa gesekan udara dan rotasi bumi tidak mempengaruhi selama benda bergerak. Dalam gerak parabola dalam bidang vertikal ada yang dipengaruhi percepatan gravitasi bumi dan tanpa dipengaruhi gravitasi bumi. Dalam hal ini dengan menganggap dapat terjadi pada ruang hampa, tanpa adanya pengaruh percepatan gravitasi atau planet-planet yang lain. Jika sebuah benda melakukan gerak lurus beraturan ke arah sumbu $x$ dan gerak lurus berubah beraturan tanpa kecepatan awal ke arah sumbu y, maka lintasan benda tersebut akan berbentuk suatu parabola terbuka ke atas. Materi yang mendasari pembahasan ini adalah

\section{Gerak beraturan:}

Pada arah mendatar berlaku gerak beraturan dengan kecepatan $v_{x}$ konstan, sehingga komponen jarak tempuh mendatar dapat dirumuskan menjadi:

$$
x=v_{x} \cdot t
$$

\section{Gerak berubah beraturan :}

Pada arah vertikal berlaku gerak berubah beraturan dengan kecepatan awal nol $\left(\mathrm{v}_{\mathrm{o}}=0\right)$, sehingga komponen jarak tempuh mendatar dapat dirumuskan menjadi:

$y=1 / 2 a^{2}$

Kecepatan benda di titik seberang setelah selang waktu $t$ dihitung dengan menghitung $v_{x}$ yang merupakan kecepatan arah sumbu $x$ (konstan / GLB) dan $v_{y}$ yang merupakan kecepatan arah sumbu y dengan $v_{0}=0$ (GLBB).

\section{Gerak Parabola pada Bidang Vertikal dengan Percepatan Gravitasi}

Jika sebuah bola dilemparkan ke atas dari titik 0 dengan sudut á dan dengan kecepatan awal $\mathrm{v}_{\mathrm{o}^{\prime}}$ maka bola dapat dianggap mengalami dua gerakan pada sumbu $\mathrm{x}$ dan y yang saling tegak lurus. Gerak bola berbeda antara arah sumbu $x$ dan arah sumbu $y$, yaitu: 1 ) arah sumbu $\mathrm{x}$ : gerak beraturan dengan kecepatan $\mathrm{v}_{\mathrm{ox}} ;$ dan 2) a $\mathrm{r}$ a $\mathrm{h}$ sumbu y: gerak berubah beraturan dengan kecepatan awal $v_{\text {oy }}$ dan sepanjang perjalanan bola, bola memperoleh per-lambatan $\mathrm{g} \mathrm{m} / \mathrm{s}^{2}$

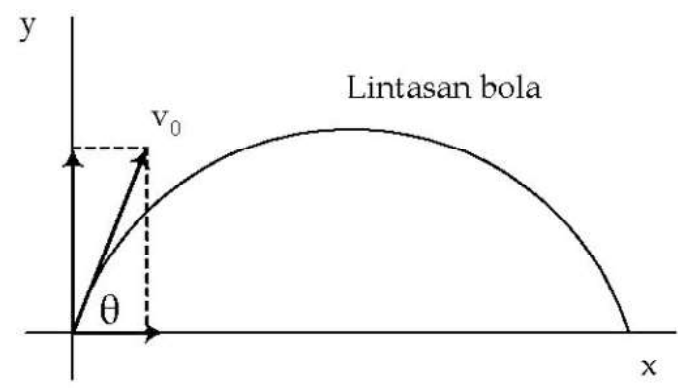

Gambar 1. Gerak Parabola.

Beberapa persamaan yang berhubungan dengan gerak bola adalah :

Sumbu $x: v_{o x}=v_{0} \cdot \cos \theta$

Sumbu $y: v_{o y}=v_{o} \cdot \sin \theta$

Jarak mendatar yang ditempuh bola padat sembarang:

$\mathrm{x}=\mathrm{v}_{\mathrm{o}} \cos \mathrm{a} \cdot \mathrm{t}$

Ketinggian pada $\mathrm{t}$ sembarang:

$y=v_{0} \sin a \cdot t-1 / 2 g t^{2}$

Persamaan kecepatan dan arah gerakan partikel:

$$
\begin{aligned}
& \mathrm{v}_{\mathrm{x}}=\mathrm{v}_{\mathrm{o}} \cdot \cos \theta \\
& \mathrm{v}_{\mathrm{y}}=\mathrm{v}_{\mathrm{o}} \cdot \sin \theta-\mathrm{g} \cdot \mathrm{t}
\end{aligned}
$$

Kecepatan total bola menggunakan teorema Phitagoras.

Arah lintasan bola terhadap horizontal adalah:

$\tan \alpha=\mathrm{v}_{\mathrm{y} / \mathrm{v}}$

Dinamika Benda yang Bergerak Parabola

Secara umum gerak sebuah benda tegar, misalnya bola sepak bola, dapat diuraikan atas gerak pusat massa benda terhadap suatu acuan yang diam, misalnya permukaan tanah dan gerak benda terhadap suatu garis atau sumbu yang melewati pusat massa benda. Jika gaya berat (gaya gravitasi) adalah satu-satunya gaya yang bekerja pada bola maka pusat bola bergerak dalam 
lintasan parabolik pada sebuah bidang vertikal. Gerakan ini merupakan gerakan melengkung tetapi dalam arah vertikal ke bawah, tidak menyamping. Untuk selang waktu yang sangat pendek dan kecepatan yang besar lengkungan parabolik tersebut mendekati bentuk garis lurus.

Gerakan kedua berupa gerak spin, yaitu gerak melingkar terhadap suatu sumbu putar. Kombinasi kedua gerak ini yang memungkinkan bola membelok ke arah samping kiri atau kanan. Jadi contoh tendangan pisang dari pemain-pemain bola terkenal seperti Carlos atau Beckam merupakan tendangan yang membuat bola memiliki kedua macam gerak di atas.

Ketika bola ditendang dan melayang di udara dengan spin/putaran bola, maka selama melawan aliran udara, menurut prinsip Bernoulli pada kedua sisi bola terjadi tekanan yang berbeda. Perbedaan tekanan ini menghasilkan gaya yang dikenal sebagai gaya Magnus, atau kadang dikenal juga sebagai gaya angkat/lift.

Bola, yang berputar dengan arah berlawanan dengan arah jarum jam di udara, akan mengalami gaya Magnus ke arah kiri. Fenomena ini terjadi akibat tekanan udara di kiri bola lebih rendah dari sisi yang lain.

Oleh karena kecepatan udara di sekitar bola relatif terhadap bola sama besar tetapi berlawanan arah dengan kecepatan titik-titik pada bola yang dekat dengan udara tersebut maka besar kecepatan udara di sekitar titik A lebih besar daripada besar kecepatan udara di sekitar titik B. Dengan memandang bahwa kerapatan udara di sekitar kedua titik sama maka menurut hukum Bernoulli untuk fluida tekanan udara di sekitar titik A lebih rendah daripada tekanan udara di sekitar titik B. Dengan kata lain bola mendapatkan tekanan udara yang lebih besar pada bagian di sekitar B daripada bagian di sekitar A. Karena tekanan adalah gaya per satuan luas maka bola mengalami gaya dorong, yang dinamakan gaya Magnus, dari arah B ke A.

\section{Metode Penelitian}

\section{Variabel dan Instrumen}

Merujuk pada pendekatan penelitian dan pengembangan (research and development), maka penelitian ini dilaksanakan dengan uji coba terbatas dengan desain 2 kelas paralel. Kelas pertama diberikan treatment dengan menerapkan model pembelajaran PBI sedangkan untuk kelas kedua dilakukan pembelajaran klasikal seperti biasanya. Langkah-langkah penelitian yang dilakukan adalah sebagai berikut: 1 ) observasi awal pada kelas XI IPA1 dan kelas XI IPA2; 2) Perencanaan dan penyusunan model; 3 ) Penerapan model PBI pada pembelajaran Fisika. Adapun desain penelitian yang akan digunakan dalam penelitian ini adalah sebagai berikut.

\section{Desain Penelitian}

\begin{tabular}{|c|c|c|c|}
\hline KELAS/KELOMPOK & PRETES & TREATMENT & POSTES \\
\hline \multirow{3}{*}{ Pertama } & $\mathrm{T}_{1}$ & $\mathrm{X}_{1}$ & $\mathrm{~T}_{1}{ }^{\prime}$ \\
\cline { 2 - 4 } & $\mathrm{T}_{2}$ & $\mathrm{X}_{2}$ & $\mathrm{~T}_{2}{ }^{\prime}$ \\
\cline { 2 - 4 } & $\mathrm{T}_{3}$ & $\mathrm{X}_{3}$ & $\mathrm{~T}_{3}{ }^{\prime}$ \\
\hline \multirow{3}{*}{ Kedua } & $\mathrm{T}_{1}$ & $\mathrm{X}_{1}$ & $\mathrm{~T}_{1}{ }^{\prime}$ \\
\cline { 2 - 4 } & $\mathrm{T}_{2}$ & $\mathrm{X}_{2}$ & $\mathrm{~T}_{2}{ }^{\prime}$ \\
\cline { 2 - 4 } & $\mathrm{T}_{3}$ & $\mathrm{X}_{3}$ & $\mathrm{~T}_{3}{ }^{\prime}$ \\
\hline
\end{tabular}

\section{Populasi dan Sampel}

Subjek penelitian adalah siswa SMA Swasta di Jakarta Selatan kelas XI IPA1 dan XI IPA 2 tahun ajaran 2008/2009. Siswa kelas XI IPA1 diberikan perlakuan khusus yaitu menerapkan model pembelajaran $P B I$ dalam pembelajaran fisika, sedangkan siswa kelas XI IPA2 menggunakan metode yang biasa diterapkan guru yang bersangkutan.

\section{Metode Pengumpulan Data}

Pembelajaran fisika dengan menerapkan model PBI diberikan sebanyak tiga seri pembelajaran. Setiap seri pembelajaran, siswa terlebih dahulu diberikan pretes $T_{1}$ kemudian diberikan perlakuan pembelajaran model $P B I$ yang telah disusun dan di akhir pembelajaran pembelajaran siswa diberikan pos tes $T_{1}{ }^{\prime}$. Setelah selesai postes $T_{1}^{\prime}$ maka uji coba seri 1 selesai, selanjutnya dilakukan analisis proses dan hasil uji coba seri 1 sebagai bahan perbaikan untuk penerapan model pembelajaran $P B I$ seri II. Begitu seterusnya sampai uji coba model pembelajaran $P B I$ seri III. Hasil yang diperoleh dari setiap seri berupa penilaian kognitif, afektif dan psikomotor. 
Pembelajaran fisika yang menerapkan model PBI diberikan sebanyak tiga seri pembelajaran. Setiap seri pembelajaran, siswa terlebih dahulu diberikan pretes $T_{1}$ kemudian diberikan perlakuan pembelajaran model $P B I$ yang telah disusun dan di akhir pembelajaran pembelajaran siswa diberikan pos tes $T_{1}^{\prime}$. Setelah selesai postes $T_{1}^{\prime}$ maka uji coba seri 1 selesai, selanjutnya dilakukan analisis proses dan hasil uji coba seri 1 sebagai bahan perbaikan untuk penerapan model pembelajaran PBI seri II. Begitu seterusnya sampai uji coba model pembelajaran PBI seri III. Hasil yang diperoleh dari setiap seri berupa penilaian kognitif, afektif dan psikomotor.

Nilai kognitif berupa skor gain yaitu selisih antara skor pretes dan postes, sedangkan afektif dan psikomotor diperoleh dari hasil observasi. Skor gain yang diperoleh kemudian diolah dan dianalisis dengan uji statistik untuk mengetahui apakah terdapat peningkatan yang signifikan pada setiap perlakuan model PBI yang dikembangkan. Untuk aspek afektif dan psikomotor dianalisis secara kualitatif. Adapun analisis efektivitas dan efisien pembelajaran dianalisis dari skor gain ternormalisasi yaitu skor gain aktual dibagi dengan skor gain maksimum (Hake, 1998). Skor gain setiap seri pembelajaran kemudian dibuat grafik untuk melihat pola perkembangannya.

\section{Hasil Penelitian dan Pembahasan}

Dalam penerapan model pembelajaran PBI pada pembelajaran fisika mengacu pada pendapat Survery dan Duffy (1995), maka rancangan model pembelajaran Problem Based Instructional dibagi ke dalam 5 fase dan diterapkan pada kelas XI IPA1. Pengembangan model $P B I$ untuk pembelajaran Fisika oleh Guru dengan materi bahasan Gerak dan Gaya dengan sub pokok bahasan: 1) gerak lurus beraturan, 2) gerak lurus berubah beraturan, 3) gerak vertikal, 4) gerak parabola, dan 5) gerak melingkar. Masing-masing materi bahasan dibuat 5 (lima) pertanyaan. Pengumpulan data dilaksanakan pada awal tahun ajaran baru diharapkan siswa termotivasi dan bersemangat belajar fisika. Jumlah siswa kelas XI IPA1 sebanyak 34 siswa. Langkah-langkah kelima Fase adalah sebagai berikut.

\section{Fase 1. Kegiatan orientasi siswa pada masalah}

Pada saat guru menjelaskan tujuan pembelajaran fisika, tampak siswa memperhatikan guru dengan seksama. Situasi kelas menjadi hening karena siswa banyak yang belum saling mengenal dengan baik. Mereka berasal dari kelas satu yang berbeda dan baru disatukan dalam jurusan IPA sehingga tampak siswa masih saling beradaptasi dan mencari teman yang cocok dengan dirinya. Guru menjelaskan kegunaan alat dan bahan yang diperlukan pada kegiatan pembelajaran, siswa memperhatikan dengan serius. Salah seorang siswa yang menanyakan kegunaan alat-alat tersebut dan bagaimana mengoperasikannya. Tampak terlihat siswa termotivasi ingin segera mencobakan alat tersebut untuk memecahkan masalah yang diajukan guru.

\section{Fase 2. Mengorganisasikan siswa untuk belajar}

Siswa dibagi dalam 7 kelompok, setiap kelompok terdiri dari 5 siswa dan satu kelompok siswa yang beranggotakan 4 orang siswa. Guru meminta siswa untuk bertanya tentang alat-alat dan bahan yang ada dihadapan mereka. Setiap kelompok diberi tugas oleh guru untuk memecahkan masalah yang terdapat pada lembar kerja siswa (LKS). Guru berjalan mendekati kelompok yang belum melakukan kegiatan diskusi maupun pembagian tugas masing-masing anggota kelompok. Guru berjalan mendekati kelompok siswa yang sedang berdikusi dan kerja kelompok dalam menggali jawaban yang dituliskan sebagai hasil diskusi kelompok. Guru menanyakan kesulitan yang dihadapi atau belum memahami topik yang sedang dibahas, dan menentukan langkahlangkah untuk memecahkan masalah.

\section{Fase 3. Membimbing penyelidikan individual maupun kelompok}

Pada fase ini guru berkeliling ruangan dan memperhatikan kegiatan masing-masing kelompok, sambil bertanya tentang kesulitan yang mungkin dihadapi oleh kelompok ataupun perorangan.

Ada satu kelompok yang sangat aktif melakukan diskusi dan telah dapat memecahkan 
masalah dengan cepat dan benar. Sementara itu ada dua kelompok yang masih sibuk membagi tugas pada anggota kelompoknya dan masih bingung menentukan langkah-langkah pemecahan masalah. Terlihat guru mendekati kedua kelompok itu dan menanyakan apa kesulitan yang dihadapinya, lalu guru memberi bimbingan dengan menguraikan langkah-langkah kegiatan yang harus dilakukan oleh anggota kelompok. Pada awal bimbingan guru memberi pengarahan kepada kelompok tentang pembagian tugas dan peran masing-masing anggota kelompok, agar semua anggota bekerja dan tidak ada yang hanya berpangku tangan (menjadi penonton) saja. Setelah itu barulah guru memberi caontoh bagaimana cara mengumpulkan informasi yang dibutuhkan oleh kelompok. Pada akhirnya guru membimbing kelompok melakukan percobaan dengan benar dan teliti, sehingga dapat memecahkan masalah.

\section{Fase 4. Mengembangkan dan menyajikan hasil karya}

Setelah semua kelompok selesai menjawab lembar tugas siswa dan memecahkan masalah, maka setiap kelompok harus membuat laporan hasil kerja kelompok yang harus dipresentasikan di depan kelas dalam diskusi umum yang dipimpin oleh guru. Laporan kerja kelompok harus dibuat secara bersama-sama, untuk itu setiap anggota kelompok harus ikut serta berperan aktif dan berbagi tugas sehingga akan menghasilkan laporan yang baik. Terlihat guru selalu mengingatkan kepada setiap kelompok agar selalu berbagi tugas dengan anggota kelompoknya, jangan dikerjakan sendiri atau berdua saja melainkan harus musyawarah seluruh anggota kelompok. Hasil karya (laporan) kelompok benarbenar dikerjakan oleh kelompok dan isinya menjadi tanggung jawab bersama.

\section{Fase 5. Menganalisis dan mengevaluasi proses pemecahan masalah}

Masing-masing kelompok mempresentasikan hasil diskusi kelompoknya, apabila ada siswa yang tidak mengerti atau berbeda dengan pendapat kelompoknya, maka guru berperan sebagai penengah dan sekaligus memberi penguatan sehingga siswa memiliki persepsi yang sama. Di samping itu guru juga berperan moderator dan memimpin diskusi kelas. Untuk itu kelompok yang maju harus dapat menjawabnya atau dialihkan ke kelompok lain ataupun siswa lain untuk menjawabnya. Apabila siswa mengalami kesulitan maka guru akan memberi penjelasan atau penguatan terhadap jawaban yang diberikan kelompok yang presentasi atau siswa lain. Diskusi berjalan hingga pada kelompok terakhir yang melakukan presentasi, begitu juga dengan diskusi kelas terus berjalan sehingga semua siswa memiliki persamaan pendapat tentang pemecahan masalah yang dihadapi. Guru sudah dapat mengevaluasi pemecahan masalah yang disajikan masing-masing kelompok. Setelah itu guru menutup diskusi dengan menyimpulkan hasil diskusi kelompok dan mengevaluasi hasil penyelidikan, pemecahan masalah siswa dan proses yang dilakukan siswa sekaligus menutup pelajaran dengan memberi tugas kepada untuk pertemuan berikutnya. Kelas XI IPA1 nilai ratarata terendah untuk pretes adalah 3,25 sedangkan nilai rata-rata tertinggi adalah 6,75 . Untuk kelas XI IPA1 nilai rata-rata terendah adalah 6,45 dan tertinggi 8,75 .

\section{Perlakuan (treatment) pertama}

Pembelajaran fisika di kelas XI IPA2 berlangsung seperti biasa, materi yang dibahas sama seperti kelas XI IPA1. jumlah siswa kelas XI IPA2 sebanyak 33 siswa. Pada awal pembelajaran fisika siswa masing-masing kelas diberi soal fisika tentang gerak sebagai pretes ternyata ada beberapa siswa saja yang mendapat nilai di atas 6,00 selebihnya mendapat nilai di bawah 5,00. Sementara itu untuk kelas 2 nilai rata-rata terendah 3,25 dan tertinggi adalah 6,25. kelas XI IPA2 nilai rata-rata terendah adalah 6,75 dan nilai tertinggi sebesar 9,00. Per-bandingan nilai Fisika untuk siswa kelas XI IPA1 dan XI IPA2 untuk lebih jelasnya dipaparkan pada grafik 1 berikut. 


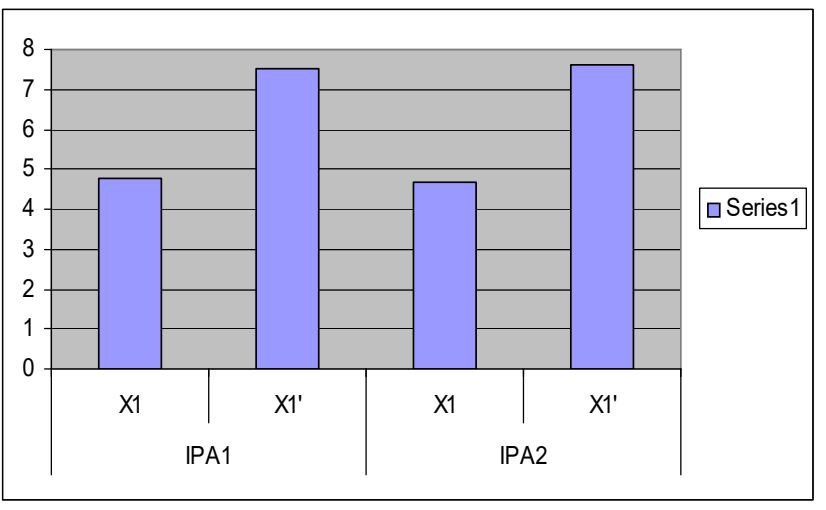

Grafik 1. Perbandingan Nilai Pretes dan Postes pada Perlakuan Pertama

Pada grafik tampak terjadi peningkatan yang signifikan antara nilai pretes dan nilai postes. Hal tersebut menunjukkan adanya pengaruh penerapan model pembelajaran $P B I$ yang dilaksanakan guru. Sebelum pembelajaran di kelas 1 dimulai guru memberikan beberapa pertanyaan yang harus dijawab oleh siswa, terlihat siswa ada yang masih kesulitan menjawabnya. Setelah siswa selesai menjawab pretes dan mengumpulkannya, guru meminta siswa untuk membentuk kelompok. Siswa dibagi dalam kelompok yang terdiri dari 5 orang siswa dan salah satu dari mereka berperan sebagai ketua kelompok. Kemudian guru memberikan seperangkat peralatan untuk melakukan percobaan tentang gerak. Pada awal pembelajaran tampak siswa masih bingung apa yang harus dilakukan terhadap alat-alat praktikum yang ada dihadapan mereka. Di antara anggota kelompok masih kelihatan asing belum saling mengenal secara dekat (karena siswa belum lama di juruskan ke IPA dan mereka berasal dari kelas satu yang berbeda) Setiap anggota kelompok hanya memegang-megang alat praktikum tanpa mengetahui kegunaan alat tersebut. Siswa masih merasa aneh melihat alat-alat tersebut. Setelah guru memberikan LKS, tampak siswa mulai memahami kegunaan alat-alat tersebut dan keterkaitan alat tersebut dengan teori yang diterimanya di kelas minggu lalu. Siswa mulai mengaitkan antara teori dengan praktiknya dan menjawab LKS dengan sebaik-baiknya. Selesai LKS di jawab berdasarkan hasil percobaan masing-masing kelompok mempresentasikan ke depan kelas. Guru bertindak sebagai moderator dan fasilitator diskusi kelas. Apabila ada anggota kelompok yang belum memahami dapat bertanya kepada kelompok yang sedang presentasi. Jika kelompok presentasi tidak dapat menjawab pertanyaan maka guru dapat menjawabnya sekaligus memberi penguatan atas jawaban yang diberikan. Diskusi kelas ini berjalan agak lambat karena kelompok yang presentasi belum dapat menampilkan dengan baik sehingga respon anggota kelompok lainnya maksimal. Hal tersebut dimungkinkan siswa belum saling mengenal dengan akrab sehingga mereka merasa kaku dan belum berani bertanya.

\section{Perlakuan (treatment) kedua}

Dari hasil pretes kelas XI IPA1 diperoleh nilai ratarata siswa terendah adalah 3,25 dan tertinggi 4,5 setelah pembelajaran yang menerapkan model PBI, nilai rata-rata siswa adalah sebagai berikut. Nilai rata-rata terendah 5,00 dan nilai rata-rata tertinggi adalah 7,35.

Proses pembelajaran fisika di kelas XI IPA2, tidak menerapkan model pembelajaran PBI. Awal pembelajaran fisika guru memberikan pretes kepada siswa untuk mengaitkan pengetahuan awal yang dimiliki siswa dikaitkan dengan tentang materi yang akan dibahas. Setelah selesai pembelajaran siswa diberi postes untuk mengetahui kemampuan siswa menerima materi yang diberikan guru. Pada pertemuan berikutnya, pembelajaran Fisika dimulai pukul 9.00. Materi yang dibahas adalah Gerak Parabola. Sebelum pembelajaran dimulai terlebih dahulu diberikan pretes kepada siswa bertujuan untuk mengetahui pengetahuan awal yang dimiliki siswa tentang yang akan dibahas. Untuk kelas 2 memiliki nilai rata-rata siswa terendah adalah 3,25 dan nilai tertinggi 4,5., sedangkan untuk kelas 2 nilai ratarata terendah adalah 6,45 dan tertinggi 8,5 . 


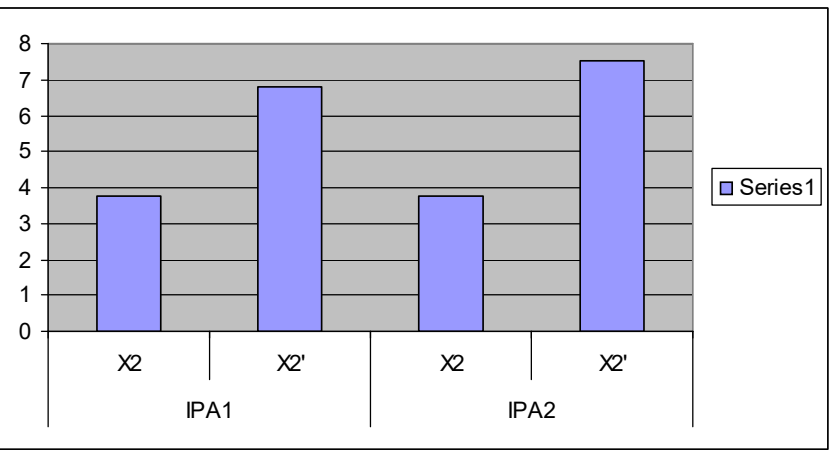

Grafik 2. Perbandingan Nilai Pretes dan Postes pada Perlakuan Kedua

Pada grafik terlihat peningkatan nilai antara pretes dan postes yang dimiliki kelas 1 tidak terlalu baik jika dibandingkan dengan nilai pretes dan postes yang dimiliki siswa kelas 2 .

\section{Perlakuan (Treatment) ketiga}

Pada pertemuan berikutnya siswa terlihat lebih akrab satu sama lain, mereka umumnya sudah saling mengenal. Tidak seperti pada pertemuanpertemuan sebelumnya siswa masih saling asing belum saling mengenal. Terlihat pula siswa sudah terbiasa mengalami model pembelajaran yang diterapkan guru. Saat guru menyiapkan perlatan untuk percobaan siswa banyak membantu, sehingga persiapan pembelajaran lebih cepat selesai dan dapat segera dimulai. Dari hasil pretes diperoleh nilai rata-rata siswa terendah 3,25 dan tertinggi sebesar 4,25 . Saat pembelajaran terlihat siswa aktif melakukan percobaan dan menjawab LKS yang diberikan guru, maka nilai rata-rata postes terendah yang diperoleh siswa adalah 7,25 dan tertinggi 9,75 .

Untuk kelas XI IPA2 nilai rata-rata siswa pada pretes terendah 3,00 dan tertinggi 4,5 sedangkan nilai postes rata-rata terendah adalah 7,00 dan tertinggi 9,00. Untuk lebih jelasnya nilai pretes dan postes siswa dipaparkan pada grafik 3 berikut.

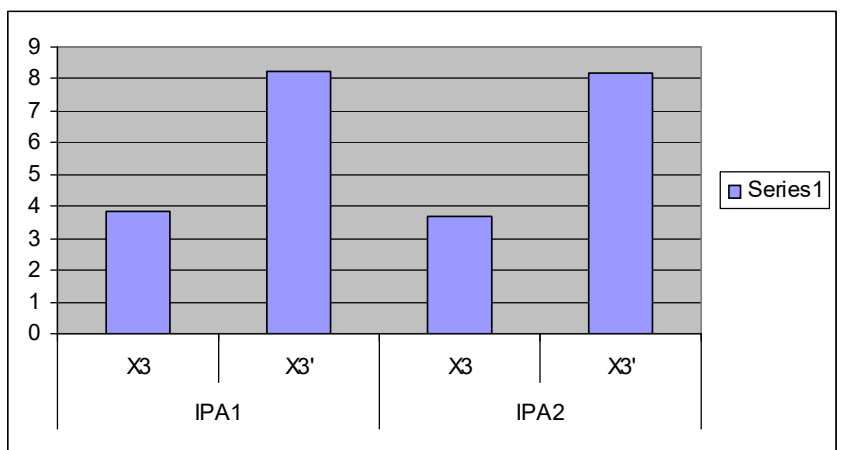

Grafik 3. Perbandingan Nilai Pretes dan Postes pada Perlakuan Ketiga

Secara umum peran guru sudah dapat sebagai fasilitator, mengamati dan memotivasi agar kerja kelompok dapat berjalan lancar, guru dapat menilai dan mengevaluasi keefektifannya. Guru melakukan evaluasi terhadap partisipasi dan aktivitasnya maupun hasil pemikiran siswa pada kegiatan diskusi dan kerja kelompok.

Belajar berdasarkan masalah adalah suatu proses pembelajaran yang diawali dari masalahmasalah yang ditemukan dalam kehidupan seharihari di masyarakat.

Pada penerapan model pembelajaran PBI dapat dibuat tahap kegiatan yang meliputi proses, tujuan dan hasil. Pada Proses, Guru memulai sesi awal PBI dengan mengungkapkan permasalahan yang akan dihadapi oleh siswa. Melakukan pendekatan kepada siswa agar tidak merasa sungkan atau takut untuk bertanya apabila ada hal-hal yang tidak dimengertinya. Untuk selanjutnya guru dapat dengan mudah mengatur dan meminta siswa untuk belajar fisika dengan model pembelajaran yang akan diterapkan oleh guru. Siswa telah dapat mengorganisasikan apa yang telah mereka pahami tentang permasalahan dan mencoba mengidentifikasi hal-hal terkait : 1) Apa yang diketahui; 2) apa yang terjadi. Setelah selesai brainstorming dan diskusi 3) bisakah itu jawabnya; siswa melanjutkan kepada 4) evaluasi kritis terhadap saran. Untuk memantapkan jawaban yang kelompok buat maka selama diskusi siswa mengajukan pertanyaan kepada guru baik secar perorangan maupun secara kelompok tentang hal-hal yang tidak mereka pahami (apa yang ingin diketahui). Hal tersebut sangat baik sekali, tanpa disadarinya siswa telah melakukan proses penyelidikan dan pemecahan 
masalah terhadap permasalahan fisika. Hal tersebut sesuai dengan tujuan dari model pembelajaran Problem Based Instruction.

Sebelum akhir sesi pertama guru mendampingi siswa untuk fokus terhadap pertanyaan yang dianggap penting. Hal tersebut perlu dilakukan guru agar siswa mampu menentukan cara membagi tanggung jawab untuk menyelidiki pertanyaan: 1) apa yang akan dilakukan; 2) Apa yang harus dilakukan sebagian dari kita; dan 3) siapa yang melakukan apa. Hasilnya cukup memuaskan masing-masing sudah dapat berperan aktif dalam kegiatan kelompoknya masing-masing, tidak ada siswa yang diam dan berpangku tangan saja atau tidak ada siswa yang merasa lebih dari siswa lainnya, semua sama tidak ada perbedaan. Maju bersama dan tidak ada siswa yang tertinggal atau ditinggalkan itulah prinsip kelompok yang harus dipuji dan diberi penghargaan. Itulah salah satu keunggulan model pembelajaran $P B I$.

Tujuan, dengan menerapkan model pembelajaran PBI guru dapat membuat siswa termotivasi, berusaha menyelesaikan permasalahan yang akan dihadapi dalam pembelajaran dan dalam kehidupan sehari-hari. Hal tersebut tergambar dari pertanyaan-pertanyaan yang dilontarkan siswa terhadap masalah-masalah yang diberikan guru, proses eksplorasi yang dilakukan siswa secara berkelompok saat memecahkan masalah.

Pada pembelajaran PBI Siswa terdorong mengidentifikasi apa yang tidak mereka ketahui atau pahami. Ini melengkapi dasar mereka dalam menghadapi tantangan belajar selanjutnya. Hal tersebut dapat memacu siswa untuk lebih banyak membaca dan belajar fisika sebelum pembelajaran di kelas berlangsung, mereka telah siap menghadapi permasalahan yang akan diajukan guru maupun olehb siswa lainnya. Hal tersebut sangat positif karena siswa seakan berlomba untuk dapat menjawab tantangan yang diberikan guru dalam pelajaran fisika. Siswa selalu membekali diri dengan membaca dan belajar fisika agar dapat bersaing dengan siswa lainnya dalam mengemukakan ide-ide menjawab semua permasalahan yang ada. Apabila hal tersebut berlangsung setiap saat maka dapat dipastikan prestasi siswa akan sangat baik. Pada akhirnya siswa bisa memahami hal yang terjadi secara lengkap dan belajar menggunakan interelating ide serta pengetahuan dari bermacam-macam disiplin. Di samping itu kerja tim dan rasa kebersamaan juga akan berkembang, maka hubungan sosial siswa akan menjadi semakin baik dan sehat.

Hasil, belajar sesuai konteksnya akan diingat lebih lama dan lebih mudah dipahami oleh siswa, karena siswa mengalami sendiri proses pembelajarannya. Bagaimana siswa harus dapat bekerja secara kelompok bagaimana pengetahuan tersebut dibangun dan bagaimana proses eksplorasi tersebut dilakukan. Konteksnya yang relevan dengan kejadian dan pengetahuan yang dimiliki siswa sehingga akan lebih memotivasi siswa untuk belajar fisika lebih jauh lagi. Apabila setiap pembelajaran fisika menerapkan model PBI dapat membuat belajar fisika menjadi kebiasaan, karena belajar secara terus menerus mengarah kepada kebiasaan. Penstimulusan pengetahuan yang ada akan memfasilitasi integrasi pengetahuan baru. Apabila penerapan model PBI dapat dikatakan sebagai fasilitas, maka fasilitas ini akan selalu dibutuhkan siswa dalam belajar fisika. Fasilitas ini secara progresif akan membangun mental untuk menyimpan, mendapatkan dan mengaplikasikan pengetahuan yang dimiliki siswa. Dapat disimpulkan karak-teristika model PBI adalah : "Belajar akan lebih baik jika siswa bisa mengajukan pertanyaan dan mencari jawabnya sendiri" . berdasarkan pengalaman siswa dalam belajar fisika dengan model PBI dapat disimpulkan integrasi dari belajar membantu siswa untuk menggabungkan pemahaman kerja tim (kelompok) dan keahlian manajemen (pembagian kerja anggota kelompok) akan terbangun.

Dengan diterapkan model PBI dalam pelajaran Fisika diharapkan dapat mengurangi terjadinya miskonsepsi, sehingga konsep fisika yang diterima siswa dapat menjadi bekal pengetahuan yang berguna di masa datang. Model PBI dapat menjadi alternatif yang dipilih guru dalam mengajar fisika di kelas, sehingga siswa dapat mengalami pengalaman baru dalam belajar fisika dan dapat memahami fisika secara mendalam bahkan dapat meningkat. 


\section{Simpulan dan Saran}

\section{Simpulan}

Guru telah dapat merancang model pembelajaran Problem Based Instruction meskipun prestasi siswa yang ditreatment belum mengalami peningkatkan yang signifikan dibandingkan dengan siswa yang tidak ditreatment.

Guru membantu siswa dalam mendefinisikan dan mengorganisasikan tugas belajar yang berhubungan dengan masalah, membantu menentukan langkah-langkah memecahkan masalah pada setiap kelompok siswa

Guru telah dapat mendorong siswa untuk mengumpulkan informasi yang sesuai, melaksanakan eksperimen guna mendapatkan penjelasan dan pemecahan masalah.

Penerapan model PBI Guru memberikan bantuan seperlunya terutama tentang pembagian tugas dalam kelompok dan siswa telah dapat merencanakan dan menyiapkan karya yang sesuai seperti laporan, membantu siswa untuk berbagi tugas dengan temannya.

Guru telah membantu siswa untuk melakukan refleksi, dan mengevaluasi terhadap penyelidikan siswa dan proses yang siswa gunakan sehingga siswa dapat mengetahui kelemahan dan kekurangannya dari hasil refleksi yang dilakukan.

\section{Saran}

Guru harus lebih sering menerapkan model Pembelajaran Based Instructional dalam pembelajaran fisika agar siswa terbiasa berdiskusi dan dapat memecahkan masalah yang dihadapi yang pada akhirnya prestasi belajar siswa dapat meningkat.

\section{Pustaka Acuan}

Kepmendiknas No. 045/U/2002. Tentang kurikulum inti Pendidikan Tinggi. Kepmendiknas No. 045/U/ 2002.

Suradijono. SHR. 2004. Problem Based Learning. Apa dan Bagaimana ? Makalah seminar Pertumbuhan Inovasi Sistem Pembelajaran.

Boud \& Falleti. 1991. (dalam Saptono) (2003) di unduh dari (http://e learning.unimal.ac.id

Saptono 2003 diunduh dari http://e learning.unimal.ac.id

Savery.J.R.and Duffy. T. M. 1995. Problem Based learning An Instructional Model and Its Constructivist. Framework Educational Technology.

Undang- Undang No. 14 Tahun 2005. Tentang Guru dan Dosen 